\title{
Economic Success in East Asia and in Hong Kong
}

\author{
Lap-Kwong Ko ${ }^{1}$, May Tsang ${ }^{1} \&$ Tanzy Tang ${ }^{1}$ \\ ${ }^{1}$ Department of Management \& Marketing, Hong Kong Polytechnic University, Hong Kong, China \\ Correspondence: Dr. Lap-Kwong Ko, Department of Management \& Marketing, Hong Kong Polytechnic \\ University, M938, Li Ka Shing Tower, Hung Hom, Hong Kong, China. Tel: 852-3400-3644.
}

Received: March 30, 2017

Accepted: April 27, 2018

Online Published: May 2, 2018

doi:10.20849/abr.v3i2.377

URL: https://doi.org/10.20849/abr.v3i2.377

\begin{abstract}
This study is concerned with the organizational characteristics of Hong Kong's manufacturing firms, the business and technology strategies they adopt. Before turning to those issues, it is useful to set the study in its broad setting, which is East Asian economic development. The purpose of this paper is to set out that broad setting, focusing on the explanations put forward for Hong Kong and East Asia's economic success. Particular attention is paid to the role of technology in economic development, to the technology policies adopted by governments and to the means by which East Asian firms have developed their technological capabilities. The paper also shows that Hong Kong Special Administrative Government (HKSAR) has taken a different route to development than other East Asian economies, which may have implications for its great change in policies to support R\&D through the Research and Development Cash Rebate Scheme. Under the scheme, a company will receive a cash rebate equivalent to $40 \%$ of its expenditure in R\&D Projects.
\end{abstract}

Keywords: R\&D policies in south East Asia, South East Asia economic growth models, up-grading technological policies in Hong Kong

\section{Introduction}

There is broad agreement on a number of basic conditions, which formed the foundation for East Asia's economic success. First, firms undoubtedly benefited from low rates of interest, relatively low inflation and high rates of saving. Second, there is little doubt that achieving macroeconomic stability by 'getting the basics right' (World Bank 1993) was a key factor. Third, each "Asian dragon" developed an appropriate educational and technological infrastructure. In the early stages removing illiteracy and supplying a sound general education was important for industrial development. Once literate, children then went on to receive vocational education and by developing, adapting and improving training and education policies, each country supplied a sufficient number of skilled workers for firms to utilize. Each country set up institutes for engineering training and support for industry; many firms benefited from their services and supplies of well-trained engineers and technicians. Vocational courses, often directed towards company needs, were carried out in local universities and polytechnics.

While there is a large measure of agreement on these basic foundations of East Asian success there is nevertheless ample room for disagreement and debate on a variety of themes. At the level of political economy at least four schools of thought can be identified: the free-market thesis, the developmental state approach, neo-modernization theory and the globalization perspective (Chiu and Wong. 1997). Taking the region as their unit of analysis, adherents of the above strands each developed an "East Asian Model" by looking for the "crucial similarity" among the four "Asian dragons'. First of all, free-market advocates like Balassa (1988) and Friedman and Friedman (1980) highlighted the centrality of a well-functioning market mechanism where price signals allocate resources efficiently and effectively. On the other hand "statists" like Johnson (1987), Amsden (1985) and Wade (1988) all stress that in East Asia the state has played a much more active and extensive role in the socio-economic transformation than free-market advocates assume. Going beyond the market-versus-state debate are neo-modernization theorists, who associate economic development with cultural categories like Confucian heritage (MacFarquhar 1980) and family entrepreneurialism (Wong 1988). Meanwhile, those who adopt the globalization perspective see the "Asian Miracle" as part of the wider restructuring of the international political economy in the Post-War era (Dicken 1992; Henderson 1989).

While this literature has made a great contribution to the understanding of East Asian development, its focus on 
the regional level obscures diversity among economies. The market-versus-state debate is a good example; with free-market advocates like Friedman and Friedman (1980) selectively highlighting the case of Hong Kong whereas statists like Johnson (1987) tends to ignore the former British colony. Not surprisingly, doubts remain as to whether there is one development model in East Asia (Dowling 1994; Kuznets and Perkins, 1994).

\section{Accounting for Economic Growth}

Just as political economists have approached East Asian development in diverse ways, so have those economists whose more narrow concern is to explain the region's growth in national income. The group that has attracted most attention might be labeled "fundamentalists" (Young, 1992, 1994a, 1994b; Kim and Lau, 1994; Krugman, 1994; Collins and Bosworth, 1997), who claim that growth in the region was largely driven by increases in inputs. The fundamentalists began this debate with Young's 1992 paper, which maintains that growth in the region was input-driven; mainly capital, and that productivity increases were negligible if not zero. Young reached this conclusion by estimating the rate of the so-called total factor productivity (TFP) growth. But without any doubt, it was Krugman's (1994) paper that popularized the debate when, based on the results of Young (1992) and Kim and Lau (1994), he provided a controversial interpretation of the East Asian Miracle and compared the "Asian dragons" to the Soviet Union. The so-called "Krugman thesis" that there was no miracle behind East Asia's growth but simple capital accumulation, has important implications for the understanding of the East Asian miracle, being interpreted to mean that these countries will not be able to sustain their economic growth, and may end up like the Soviet Union.

However, as Davies (1996) pointed out, Hong Kong was an exception to the general pattern of results found by the fundamentalists. While the city certainly spent very little on research and development, and lagged behind the other Asian dragons in terms of inputs to the process of technology development, nevertheless its total factor productivity grew much more rapidly than its rivals'. The combination of 'high IQ and low technology' seemed to give Hong Kong the best of both worlds - minimal commitment of resources to the risky process of innovation but maximum return in terms of improved efficiency.

\section{The Question of "Up-grading"}

Hong Kong's unusual position is also reflected when the focus narrows further to the question of industrial "upgrading". UNCTAD (1996) compared the export pattern of four "Asian dragons" over the 1963-1990 period, and singled out Hong Kong for its loss of market share in almost half of the highly dynamic product sectors in which it had earlier built a strong market presence. In the same vein, Chow and Kellman (1993) note that while Taiwan, Singapore and South Korea have successfully "upgraded" their exports from labour-intensive and resource-based products to more technology-intensive ones through the mid-60s to early 90s, Hong Kong had the least structural transformation of commodity composition of exports over the period. While Taiwan, Singapore and South Korea appeared to have dramatically upgraded their local industrial bases in one way or another, commentators have seen it as puzzling that Hong Kong appeared to stay with labour-intensive manufacturing for more than three decades. (Chiu and Wong, 1997).

As the heart of these debates lies in the role of technology and technology policy in East Asian economic development and growth, some of the differences that emerge across nations warrant further attention.

\section{Alternative Approaches to Technology in East Asian Development}

Technology may be defined as 'information and the capability to use it' (Davies and Whitla 1995). The two primary processes involved are the acquisition of technology and its exploitation. Resources are expended to acquire (or generate) new technologies, and those are subsequently exploited for an economic return. This on-going cycle has been described by Matthews (1992), noting that at firm level 'technology strategy' provides guidance to the management of these processes, ensuring alignment between corporate objectives, business strategies and operational activities, including R\&D projects. In that case it is possible to ask "what has been the role of technology in the "Asian dragons" as they have developed over the last few decades? Chiu et al (1997) suggest that the four "Asian dragons" adapted to the restructuring era by a combination of three broad strategies. That strategy set included: first, expanding outward investment and relocating production processes in other developing countries; second, raising the level of regional integration in trade; and third, increasing the value-added content of their exports and up-grading their industrial structure. Most of the Asian dragons paid greatest attention to the third strategy, leading the assimilationists (Dahlman and Westphal, 1981; Dahlman et al., 1987; Hobday, 1994a, 1994b, 1994c, 1995; Romer, 1993a, 1993b; Pack, 1993; Pack and Page, 1994a, 1994b; Nelson and Pack, 1996), to argue that the essential component of the recipe followed by East Asian countries was the acquisition and mastery of foreign technology, and the capacity to put that technology into practice. Moving beyond that approach, having learned from the technologically more mature nations, some of the East Asian nations have begun to develop their own 'innovation-capability'. Throughout the last decade South Korea has vigorously shifted its emphasis from "imitation strategy" towards "innovation strategy" by intensifying 
in-house R\&D (Kim 1997). Likewise, Taiwan has been keen on acquiring cutting-edge capability in various technology areas such that a globally orientated strategy is now a real possibility for a handful of firms (Lee and Pecht 1997). Even Singapore has developed locally a world-class engineering capability in spite of predominance of Multinational Corporations, as for example; strong precision engineering industries that have been built up around the hard disk drive sector (Wong 1996). Hong Kong, by contrast, placed heavy reliance on the relocation strategy, and in consequence is often described as "failing" to realize the prospects for up-grading.

These differences amongst the four "Asian dragons" may in part be attributable to the different policies adopted by both government and the private sector in respect of industrial technology development. It is common to regard the stimulation of industrial research and development $(R \& D)$ as the main objective for technology policy. According to the figure provided by Henry Tang, the secretary for Commerce, Industry and Technology of HKSAR in July 2002 the comparative figures are shown in Table 1.

Table 1. Expenditure on R\&D: 3 Countries

\begin{tabular}{llll}
\hline Country & Year & Total R\&D (US\$ billion) & \% GDP \\
\hline Singapore & 2002 & 1.74 & 2.05 \\
Taiwan & 2002 & 6 & 1.89 \\
Hong Kong & 2002 & 0.79 & 0.49 \\
\hline
\end{tabular}

Source: Tang $(\overline{2002)}$

As Tang said, "Indeed, Hong Kong's total R\&D expenditure lags behind our neighbors by quite a wide margin. Taking Singapore and Taiwan as examples, they spent a total of US $\$ 1.74$ billion and US\$6 billion respectively in the year 2000 as compared with US\$0.79 billion in Hong Kong. Indeed, R\&D expenditure in Hong Kong only accounted for $0.49 \%$ of our GDP, as compared with $1.89 \%$ for Singapore and $2.05 \%$ for Taiwan." Most of our R\&D activities are Government funded and concentrated in our Universities. Such activities account for more than $80 \%$ of the total R\&D activities in Hong Kong. In Singapore, the situation is quite the opposite as more than $60 \%$ of the R\&D activities are funded by the private sector. As pointed out by Tang, a growing base of R\&D capabilities also permits better and faster diffusion of new technologies within the economy. Added to this, market failures in stimulating the growth of a "technology culture" in an industrializing economy is very important. Although Tang said that the HKSAR Government has fully committed and will invest in R\&D activities, I have to study the other dragons' technology policy in order to get some insight for next section.

Hobday (1995) provides a useful overview of the differences amongst the four Asian dragons, as shown in Table 2 , focused on the relative open-ness of their economies and the extent of government intervention. Both South Korea and Singapore followed highly interventionist policies. Singapore intervened mainly indirectly through subsidies and other inducement to transnational corporations as well as infrastructural and educational policies, often for the benefit of specific foreign firms. South Korea intervened both indirectly and directly in the strategic affairs of the Chaebol, offering cheap finance, setting export targets, preventing some diversifications and allowing others.

Table 2. Alternative approaches to industrial development in East Asia

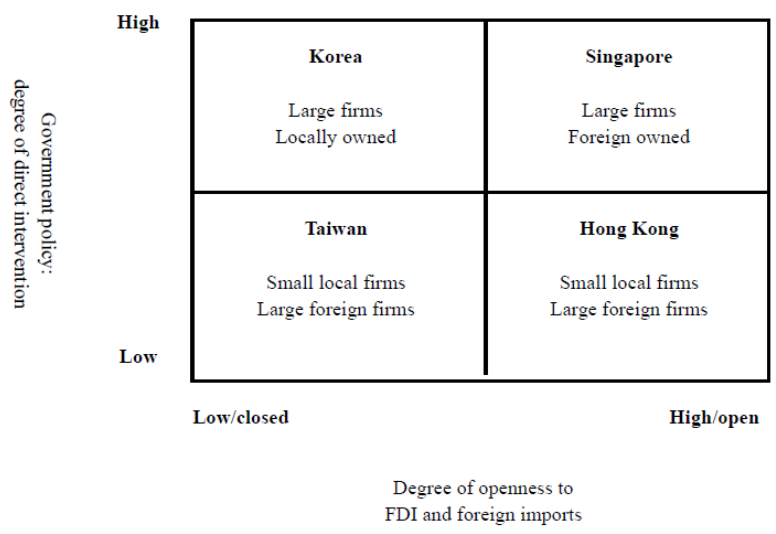

Source: Hobday, M (1995) 
In the case of Taiwan, the government intervened selectively in scale-intensive areas such as semiconductors, but left most export activity to the strategies of private companies in the market place. Hong Kong, on the other hand, pursued a non-interventionist, laissez-faire approach to industry and economic development.

Table 1.2 also illustrates important differences in the orientation of industrial policy. While Hong Kong and Singapore pursued strictly conventional export-led policies and Yu (1998) pointed out that Hong Kong embarked on its export-led industrialization in the early 1950s and experienced rapid growth in the 1960s. During 1968-71, the average growth rate in real terms was approximately $6.5 \%$ and by 1971, the per capita income reached HK\$6,096, placing it second behind Japan in East Asia (Riedel, 1974, p. 11). BY 1992, the GDP reached HK\$742,582 million. After more than three decades of rapid growth, Hong Kong has emerged as one of the richest economies in Asia. South Korea and Taiwan combined these policies with import substitution, controlling or banning imports to protect local firms and using government procurement to stimulate local enterprise. South Korea was the most restrictive, receiving much less Foreign Direct Investment (FDI) than the two city-states, despite its greater size. Taiwan often negotiated the terms of FDI and tied transnational corporations to local content rules and export targets. In sharp contrast, Singapore and Hong Kong encouraged FDI with low taxation, special incentives and welcoming policies and schemes, allowing a degree of freedom seldom witnessed in South Korea and Taiwan.

Regarding company size, while Taiwan and Hong Kong depended to a large extent on small, Chinese Family Businesses (CFBs), the South Korean Government patronized the very large conglomerates. South Korean technology policies resulted in highly concentrated industrial structures, with the Chaebol. By contrast, in Hong Kong and Taiwan, small firms proliferated, resulting in a highly dispersed industrial structure.

Technology Policy and company strategy was closely entwined. Small size led overseas Chinese firms to rely on speed and flexibility, while the large South Korean companies took a high-volume, process-intensive approach. Many Taiwanese and Hong Kong firms specialized in fast changing market niches. South Korean Technology policies and corporate strategies owed much to the Japanese keiretsu, which provided a nearby role model. By contrast, Taiwanese approach drew from a variety of sources. Local firms combined their traditional overseas Chinese business styles with modern management training received in leading US corporations, universities and business schools. Many Taiwan's high-technology firms owe more to the American management influence than to the Japanese.

Regarding ownership, Taiwan and South Korea relied mostly on locally owned firms, while Singapore depended almost entirely on foreign Transnational Corporations (TNCs).

Overall, the evidence shows striking contrasts between the four non-Japanese models of East Asian development. Policy diversity led to plurality in industrial concentration, corporate ownership and strategy, patterns of innovation and paths of industrial development. Second, the latecomers responded to the outward-looking, export-led industrial policies of each country. Export-led growth provided the framework to enable firms to overcome their dislocation from the centers of world innovation and demanding international markets, providing the demand-pull for innovation in East Asia. Where import-substitution was evident, as in the case of South Korea and Taiwan, import restrictions were conducted within an overall policy of export-led growth. Exports acted as a focusing device for technology investments and encouraged the growth of a variety of institutions to enable exports to flourish. Arrangements such as OEM, joint ventures, licensing and sub-contracting were encouraged by government policies, allowing firms to acquire and adapt foreign technologies.

Finally, governments intervened to ensure that the entrepreneurial base was strong enough to lead industrialization. Without a sufficiently talented cadre of firms, no industrial strategy can be successful almost by definition. Technology policies to overcome what can be called entrepreneurial (or corporate) failure took various forms. In Singapore in the 1960s the quality and quantity of local firms was judged by government to be inadequate to lead industrialization. It therefore set about attracting Transnational Corporations (TNCs) to develop the electronics industry and tool control of other industries itself. In South Korea, market mechanisms and institutions were also inadequate; the domestic government built up the large Chaebol to overcome the problem of corporate failure. In Taiwan, in many scale-intensive sectors state-owned firms were established to organize industrial development. However, in Hong Kong, firms adopted relocation strategies on ad hoc basis, which is why Hong Kong is often described as being more than a decade behind in technology as compared with the other competitor. Table 3 provides an overview of the different industry and technology policies adopted in East Asia, taken from Lall and Teubal (1998 and 2009). 
Table 3. A Comparison of industrial visions and strategies in the four "Asian dragons"

\begin{tabular}{|c|c|c|c|c|}
\hline \multirow{5}{*}{ 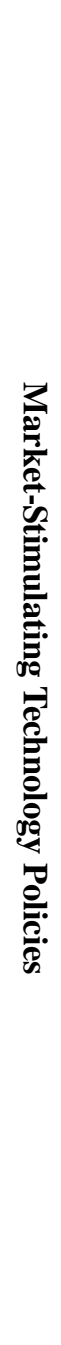 } & & $\begin{array}{lll}\text { eepening } & \text { Raising } & \text { Local Fdi Strategy } \\
\text { dustrial Structure } & \text { Content } & \end{array}$ & $\begin{array}{l}\text { Raising } \\
\text { Technological } \\
\text { Effort }\end{array}$ & $\begin{array}{l}\text { Promotion of } \\
\text { Large Local } \\
\text { Enterprises }\end{array}$ \\
\hline & $\begin{array}{l}\text { Hong } \\
\text { Kong }\end{array}$ & \multicolumn{3}{|c|}{$\begin{array}{lcc}\begin{array}{l}\text { None, leave } \\
\text { market forces }\end{array} & \begin{array}{c}\text { to None, leave to None, leave to market None, } \\
\text { market forces } \\
\text { forces }\end{array} & \begin{array}{l}\text { except None } \\
\text { for SMEs }\end{array}\end{array}$} \\
\hline & gapore & \multicolumn{3}{|c|}{$\begin{array}{lcccr}\text { Very } & \text { strong push None, } & \text { but Aggressive targeting None for local None, } & \text { but } \\
\text { into } & \text { specialized subcontracting and screening of firms, but MNCs some public } \\
\text { high } & \text { skill/tech promotion } & \text { for MNCs, direction into targeted to increase sector } & \\
\text { industry for export SMEs } & \text { high value-added R\&D } & \text { enterprises } \\
\text { markets, but } & \text { activities } & \text { enter targeted } \\
\text { without protection } & & \text { areas }\end{array}$} \\
\hline & Taiwan & \multicolumn{3}{|c|}{ 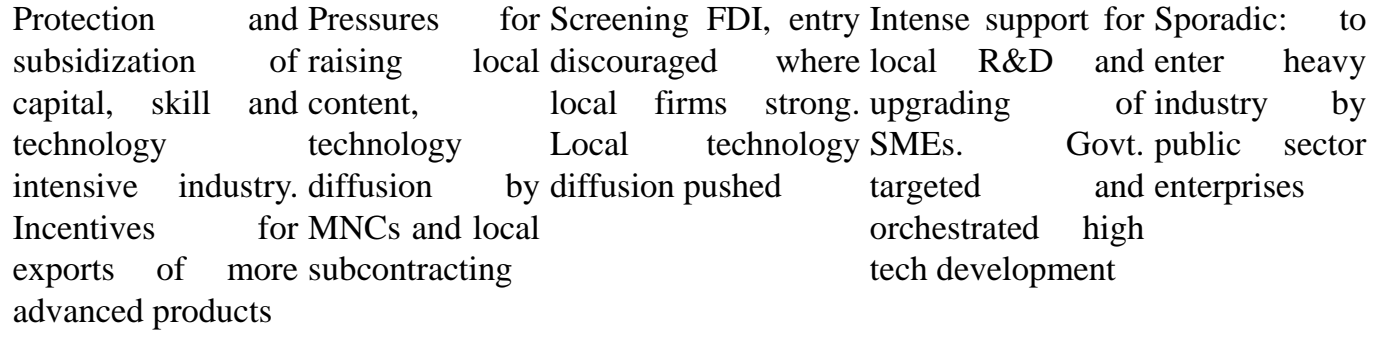 } \\
\hline & uth & \multicolumn{3}{|c|}{$\begin{array}{l}\text { Strong trade and Stringent local FDI kept out unless Ambitious plans Sustained } \\
\text { credit interventions content rules, necessary } \\
\begin{array}{llll}\text { to promote capital, creating support technology access or advanced industry, giant private } \\
\text { skill and technology industries, exports, joint ventures heavy investment conglomerates } \\
\text { intensive industry, protection of and } & \text { licensing in technology to internalize } \\
\text { especially heavy local suppliers, encouraged } & \text { infrastructure. markets, lead } \\
\text { intermediates and subcontracting } & \text { Targeting } & \text { of heavy } \\
\text { capital goods. promotion } & \text { strategic } & \text { industry, create } \\
\text { Selective export } & \text { technologies } & \text { export brands }\end{array}\end{array}$} \\
\hline
\end{tabular}

Source: Adapted from Lall and Teubal (1998 and 2009)

\section{Conclusions}

This research paper has set out the background against which this study is to be set. In common with the other East Asian 'dragons', Hong Kong has seen economic success sustained over a period of many decades. However, the city has also differed from its neighbors in a number of key respects. First, and most broadly, Hong Kong has devoted very few resources to the process of technology development. And yet, at the same time, it has experienced superior growth in total factor productivity, suggesting that in some way the benefits of technology development are being acquired, without the costs being incurred. Second, throughout the colonial period, government policy towards the development of industry and technology was much less interventionist and supportive than in the other 'dragons'. Thirdly, of the broad development strategies open to industries in East Asia, Hong Kong firms have chosen the re-location of their activities into developing countries (mostly China) in preference to up-grading the local industrial base.

While many commentators have interpreted Hong Kong's technological performance as a 'failure', that conclusion sits uncomfortably with the evidence on rapidly improving efficiency. At the end, the Hong Kong Special Administrative Government (HKSAR) takes to promote and support The innovation and Technology Industry. That will be the key economic areas that the HKSAR Government seeks to further develop. Formally established on 20 Nov 2015, the Innovation and Technology Bureau (ITB) is responsible for formulating holistic policies relating to innovation and technology; strengthening the co-ordination among the Government, industry, academia and research sectors; and expediting the development of innovation, technology and related industries in Hong Kong. The Bureau comprises an innovation and Technology Branch and overseas the operation of the 
Innovation and Technology Commission (ITC) and the Office of the Government Chief Information Officer (OGCIO).

In Nov 2016, 1 500-Million Technology Voucher Program (TVP) was launched on a pilot basis under the technological services and solutions to improve productivity, or upgrade or transform their business processes.

Other work priorities of the ITB include collaborating with relevant policy bureau and government departments, as well as the public and private sectors, in examining Smart initiatives, facilitating further use of public sector information and big data applications, and developing Hong Kong into a connected Wi-Fi City.

The Research and Development $(\mathrm{R} \& \mathrm{D})$ Cash Rebate Scheme aims to reinforce the research culture among business enterprises and encourage them to establish stronger partnership with designated local public research institutions. Under the scheme, a company will receive a cash rebate equivalent to $40 \%$ of its expenditure in $\mathrm{R} \& \mathrm{D}$ projects.

To assist local technology start-ups and entrepreneurs to get through the most vulnerable inception stage of their businesses, the Hong Kong Science and Technology Parks Corporation (HKSTP) offers three incubations:

Incu-Tech for new technology start-ups (three years)

Incu-Bio for those involved in biotechnology (four years); and

Incu-App for those focused in web-and smartphone-based apps (18 months)

The incubation programs provide subsidized office space, financial aid package as well as comprehensive range of support services for the incubates during the incubation period. Last but not least, In May 2017, the ITB launched a 500 Million Innovation and Technology Fund for Better Living to subsidise innovation and technology projects which will bring more convenient, more comfortable and safer living to the public, or those addressing the needs of specific community groups.

\section{References}

Adler, P. S, Campbell, M., \& Laurent, L. (1989, June). In Search of Appropriate Methodology: From Outside the People's Republic of China Looking in. Journal of International Business Studies, 20(1), 61-74.

Adler, P. S. (1989). Technology Strategy: A Guide to the Literatures. Research in Technological Innovation, Management and Policy, 4, 25-151.

Advisory Committee on Diversification. (1979). Report of the Advisory Committee on Diversification. Hong Kong Government Press.

Amsden, A. (1985). The State and Taiwan's Economic Development (P. B. Evans, D. Rueschemeyer \& T. Skocpol (eds.), pp. 78-106.). Cambridge University Press.

Amsden, A. (1997). Manufacturing Capabilities - Hong Kong's New Engine of Growth. In Berger \& Lester (Eds.), Made by Hong Kong. Hong Kong: Oxford University Press.

Anderberg, P. (1973). Cluster Analysis for Applications. New York: Academic Press.

Anderson, P. (1987). An Approach for Confirmatory Measurement and Structural Equation Modeling of Organizational Properties. Management Science, 33(4), 525-541.

Andrews, M. (1971). The Concept of Corporate strategy. New York: Dow Jones-Irwin.

Balassa, B. (1988). Lessons of East Asian Development: An Overview. Economic Development and Cultural Change, 36, SZ73-90.

Banker, et. al. (1996). A Framework for Analyzing Changes in Strategic Performance. Strategic Management Journal, 17, 693-712.

Berger, S., \& Lester, R. (1997). Made by Hong Kong. Hong Kong: Oxford University Press.

Bhalla, B., Gaurav, P., \& Lin, L. (1987). Cross Cultural Marketing Research: A Discussion of Equivalence Issues and Management Strategies. Psychology and Marketing, 4(4), 275-285.

Brislin, R. (1970). Back-Translation for Cross-Cultural Research. Journal of Applied Psychology, 1, 185-216.

Brown, S. L., \& Eisenhardt, K. M. (1995). Product Development: Past Research, Present Findings and Future Directions. Academy of Management Review, 20(2), 343-378.

Buzzell, R, D., \& Bradley T. G. (1987). The PIMS Principles: Linking Strategy to Performance. New York: Free Press. 
Capon, N., Farley, J., \& Hoenig, S. (1996). Toward an Integrative Explanation of Corporate Finance Performance. Amsterdam: Kluwer Press.

Carney, M. (1998a). The Competitiveness of Networked Production: The Role of Asset Specificity and Trust. Journal of Management Studies, 35(4), 457-479.

Carney, M. (1998b). A Management Capability Constraint? Obstacles to the Development of the Overseas Chinese Family Business. Asia Pacific Journal of Management 15, 137-162.

Carney, M., \& Davies, H. (1999). From Entrepot and Entrepot via Merchant Manufacturing Organizational Capabilities and The Structure of Hong Kong Industry. Asia Pacific Business Review, 6(1), Autumn, 13-32.

Chavravarthy, P. (1986). Measuring Strategic Performance. Strategic Management Journal, 7, 437-458

Chi'en, R. (1994, March). Do we still Love Laissez-faire? Hong Kong's New Industrial Policy. Text of a Speech Given at Hong Kong Economics Association.

Child, J. (1972, January). Organizational Structure, Environment and Performance: The Role of Strategic Choice. Sociology, 6, 1-22.

Child, J. (1997). Strategic Choice in the Analysis of Action, Structure, Organizations and Environment. Retrospect and Prospect Organization Studies, 18(1), 43-76.

Child, J. (2000). External Examiner's Comments on C. Ma's Thesis.

Chiu, S., \& Wong, K. C. (1997). Restructuring Without Up-grading: A Sociological Study on Hong Kong Electronics Industry, 1978-1996. Master of Philosophy from the Department of Sociology. The Chinese University of Hong Kong.

Chiu, S., \& Wong, K. C. (2001). Technology Without Catching Up. Asia Pacific Research Institute, the Chinese University of Hong Kong.

Chow, I., \& Kellman, P. (1993). The Engine of Growth in East Asia. New York: Oxford University Press.

Collins, S., \& Bosworth, B. (1997). Economic Growth in East Asia: Accumulation Versus Assimilation. In W. C. Brainard \& G. L. Perry (Eds.), Brookings Papers in Economic Activity (Vol. 2, pp. 135-203).

Commission on Technology and Innovation (CTI). (1999). Report to the Chief Executive.

Dahlman, C., \& Westphal, L. E. (1981, November). The Meaning of Technological Mastery in Relation to Transfer of Technology. The Annals of the American Academy of Political and Social Science, 458, 12-26.

Dahlman, C., Larson, R., \& Westphal, L. E. (1987). Managing Technological Development: Lessons from the Newly Industrializing Countries. World Development, 6, 759-75.

Dart, \& Deng. (1994). Porter's (1980) Generic Strategies as Determinants of Strategic Groups Membership and Organization Performance. Academy of Management Journal. 27, 467-488.

Davies, H. (1996, October). High IQ and Low Technology: The Key to Hong Kong Success. Long Range Planning, pp. 685-691.

Davies, H. (1998). The Persistence of Key Capabilities in Flexible Production Networks: The Watch Industry in Switzerland and Hong Kong/China. In Strange, R., Slater, J., \& Wang, L, (Eds.), Trade and Investment in China: The European Experience. London: Routledge.

Davies, H. (1999). The Future Shape of Hong Kong's Economy: Why High Technology Manufacturing will prove to be a Myth. In Fosh, P., Snape, E., \& Chan, A. (Eds.), Return to China: Management and Labor in Hong Kong (pp. 43-58). London: Routledge.

Davies, H., \& Ellis, P. (2000, December). Porter's Competitive Advantage of Nations: Time for The Final Judgment?. Journal of Management Studies, 37(8), 1189-1213.

Davies, H., \& Ma, C. (2000, May 26-28) Do "Up-grading” Strategies Improve the Performance of Hong Kong Manufacturing Firms? An Empirical Analysis of the Watch Making Industry. Paper Presented at The International Conference on Global Economic Transformation after The Asian Economic Crisis The Chinese University of Hong Kong.

Davies, H., \& Ma, C. (2003). Strategic Choice and the Nature of the Chinese Family Business. Organization Studies, 24(9), 1405-1435.

Davies, H., \& Walters, P. (2004). Emergent Patterns of Strategy, Environment and Performance in a Transition Economy. Strategic Management Journal, 25, 347-364. 
Davies, H., \& Whitla, P. (1995). Technology Transfer to China: The Experience to Date. In Davies, H (Ed.), China Business: Context and Issues (pp. 190-214).

Deshpande, R., Farley, J., \& Webster, F. (1993, January). Corporate Culture, Customer Orientation and Innovativeness in Japanese Firms: A Quadrad Analysis. Journal of Marketing. 57, $23-27$.

Dess, G., \& Davis, P. (1984). Porter's (1980) Generic Strategies as Determinants of Strategic Group Membership and Organizational Performance. Academy of Management Journal. 27, 467-488.

Dess, G., \& Robinson, H. (1984). Measuring Organizational Performance in the Absence of Objective Measures. Strategic Management Journal. 5(3), 265-273.

DeVellis, R. F. (1991). Scale Development: Theory and Application. Newbury Park: Sage.

Dicken, P. (1992.) Global Shift: The Internationalization of Economic Activity (2nd ed.). London Paul Chapman Publishing.

Dillman, M. (1978). The Total Design Method. New York: John Wiley.

DiMaggio, P., \& Powell, W. (1983). The Iron Cage Re-visited: Institutional Isomorphism and Collective Rationality in Organizational Fields. American Sociological Review, 48, 147-160.

Doty, et. al. (1994). Fit, Equifinality, and Organizational Effectiveness: A Test of Two Configuration Theories. Academy Management Journal, 36, 1196-1250.

Dowling, J, M. (1994). Is There an Asian Industrial Growth Paradigm?. Journal of Asian Economies, 5(4), 525-535.

Ellis, P., \& Pecotich, P. (2001, Feburary). Social Factors Influencing Export Imitation in Small and Medium-sized Enterprises. Journal of Marketing Research, 38, 119-130.

Enright, M. J., \& Scott, E. E. (2003). Internal Consultancy Report- 2003 to the Invest-HK.

Enright, M. J., \& Weder, R. (1995). Studies in Swiss Competitive advantage. Berne: Peter Lang.

Enright, M. J., Frances, A., \& Saavedra, E. S. V. (1996). The Challenge of Competitiveness. New York: St Martin's Press.

Enright, M. J., Scott, E. E., \& Dodwell, D. (1997). The Hong Kong Advantage. Hong Kong: Oxford University Press.

Fahey, J. (1998). Macro Environment Analysis for Strategic Management. St. Paul, MN: West Publishing.

Fok, J. T. Y. (1991). Electronics, Doing Business in Today's Hong Kong (4th ed.).

Fornell, P. (1982). A Second Generation of Multivariate Analysis (In Claes Fornell ed.). New York: Praeger.

Friedman, M., \& Friedman, R. (1980). Free to Choose. Harmondsworth: Penguin.

Fryxell, G. (1990). Business-level Process R\&D: Patterns and Returns Under Different Generic Strategic Orientations. International Journal of Technology Management, 5(1), 41-63.

Fung, V. (1996, July 4). Hong Kong Competing into the 21st Century. Speech Given to the Hong Kong Management Association.

Gereffi, G., \& Korzeniewicz, M. (1994). Commodity Chains and Global Capitalism Westport. Conn: Greenward Press.

Greenley. (1995). Market Orientation and Company Performance: Empirical Evidence From UK Companies. British Journal of Management, 6, 1-13

Habibie, B. J. (1993, January 25). Kertas posisi seri dialog pembangunan; pembangunan ekonomiberdasarkn nilaitambah dengan orientasi pembangunan teknologi dan industry Conference Paper. Centre for Information and Development Studies, Jakarta.

Hair, J., Anderson, R., Tatham, R., \& Black, W. (1992). Multivariate Data Analysis (3rd \& 5th eds.). New Jersey: Prentice-Hall.

Hamilton, G., \& Biggart, C. (1988). Market, Culture and Authority: A Comparative Analysis of Management and Organization in the Far East. American Journal of Sociology, 94, Supplement, 552-594.

Harjani, H. (1999). A Comparison of Small Chinese and Indian Trading Businesses in Hong Kong: An Empirical Study Based on the Concept of the Chinese Family Businesses. Hong Kong: Department of Business Studies, the Hong Kong Polytechnic University. 
Hattie, J. (1985, June). Methodology Review: Unidimensionality of Tests and Items. Applied Psychological Measurement. 9, 139-164

Hayes, M., \& Wheelwright, P. (1984). Restoring Our Competitive Edge: Competing Through Manufacturing. New York: Wiley.

Henderson, J. (1989). The Globalization of High Technology Production, Society, Space, and Semiconductors in the Restructuring of the Modern World. London: Routledge.

Hobday, M. (1994a). Export-Led Technology Development in the Four Dragons: The Case of Electronics, Development and Change. The Journal of Development Studies, 25, 333-361.

Hobday, M. (1994b.) Technological Learning in Singapore: A Test Case of Leapfrogging. The Journal of Development Studies, 30, 831-858.

Hobday, M. (1994c). Innovation in East Asia: Diversity and Development. In Dodgson, M. \& Rothwell, R. (Eds.), The Handbook of Industrial innovation. Cheltenham: Edward Elgar.

Hobday, M. (1995). East Asian Latecomer Firms: Learning the Technology of Electronics. World Development, 23, 1171-1193.

Hobday, M. (1995). Innovation in East Asia - The Challenge to Japan. Cheltenham: Edward Elgar.

Hong Kong Centre for Asian studies. (1995). Economic Development in East and South East Asia, pp. 13-29. Hong Kong Centre for Asian studies, University of Hong Kong.

Hong Kong Electronic Industries Association Ltd. (2002-2003). Annual Directory of Hong Kong Electronic Industry. A Publication from the Hong Kong Electronic Industries Association Ltd.

Hong Kong Productivity Council. (1982). Report on Hong Kong Electronics Industry.

Hong Kong Special Administrative Region, Census \& Statistics Department. (2000). Report on 2000 Annual Survey of Industrial Production.

Hong Kong Trade Development Council -HKTDC. (1998). Hong Kong's Manufacturing Industries: Current Status and Future Prospects. Hong Kong: Research Department, HKTDC.

Hong Kong Trade Development Council -HKTDC. (1999). Singapore and Taiwan as Source of Competition and Markets for Hong Kong Electronics Exports. Research Department, HKTDC.

Hsueh, L. K. (1976). The Transforming Economy of Hong Kong 1951-1973. Hong Kong Economic Papers.

Johnson, C. (1987). Political Institutions and Economic Performance: The Government-Business Relationship in Japan, South Korea and Taiwan. In F. Deyo (Ed.), the Political Economy of East Asian Industrialization (pp. 136-164). New York: Cornell University Press.

Ketchen, D. J., \& Christopher, L. S. (1996). The Application of Cluster Analysis in Strategic Management Research: An Analysis and Critique. Strategic Management Journal, 17, 441-458.

Kim, L. S. (1997). Imitation to Innovation: The Dynamics of Korea's Technological Learning. Boston, M.A: Harvard Business School Press.

Kim, L. S., \& Lims, H. J. (1988). Environment, Generic Strategies and Performance in a Rapidly Developing Economy: A Taxonomic Approach. Academy of Management Journal, 31(4), 802-827.

Kim, L.S., \& Lau, L. (1994). The Sources of Economic Growth of The East Asian Newly Industrialized Countries. Journal of Japanese and International Economies, 8, 235-271.

King, A., Y. C., \& Leung D, H. K. (1975). The Chinese Touch in Small Industrial Organization. Hong Kong: Social Research Center, Chinese University of Hong Kong.

Klein, J. G., Ettenson, R., \& Morris, M. D. (1998, January). The Animosity Model of Foreign Product Purchase: An Empirical Test in the People's Republic of China. Journal of Marketing, 62(1), 89-100.

Kohli, A., \& Jaworski, B. (1990, April). Market Orientation: The Construct, Research Propositions and Managerial Implications. Journal of Marketing, 54, 1-18.

Krugman, P. (1994, November - December). The Myth of Asia's Miracle. Foreign Affairs, 62-78.

Kuznets, P., \& Perkins, J. (1994). Asian Industrialization: Is There a Paradigm. Journal of Asian Economics, 5, 491-7.

Kwong, K. S. (1997). Technology and Industry. Hong Kong: City University of Hong Kong Press. 
Lall, S., \& Teubal, M, (1998). Market-Stimulating Technology Policies in Developing Countries: A Framework with Examples from East Asia. World Development, 26, 1369-1998.

Lazerson, M. (1995). A New Phoenix: Modern Putting-out in The Modena Knitwear Industry. Administrative Science Quarterly, 40, 34-59.

Lee, J. (1996). Culture and Management - A Study of Small Chinese Family Business Management. Journal of Small Business Management, 34(3), 63-67.

Lee, J., \& Davies, H. (1995). Transforming Hong Kong Manufacturing to Services. In Davies, H. (Ed.), China Business: Context and Issues (pp. 22-36). Hong Kong: Long man.

Lee, K. S., \& Pecht, P. (1997). The Taiwan Electronics Industry. Florida: Stanford University Press.

Leung, C. K., \& Wu, C. T. (1995). Innovation Environment, R\&D linkages and Technology Development. Regional Studies, 29(6), 533-546.

Luo, Y. S., \& Chen, M. (1997). Does Guanxi Influence Firm Performance?. Asia Pacific Journal of Management $14,1-16$.

MacFarquhar, R. (1980, Feburary 9). The Post-Confucian Challenge. The Economist, 67-72.

March. J., \& Sutton, R. (1997, November-December). Organizational Performance as a Dependent Variable. Organization Science, 8(6), 698-706.

Matthews, W. H. (1992). Conceptual Framework for Integrating Technology into Business Strategy. Int. J. of Vehicle Design, 13(5-6), 524-532.

McGee, J., \& Howard, T. (1989). Research Notes and Communications Strategic Groups: A Further Comment. Strategic Management Journal, 10, 105-107.

Meyer, A., Tsui, A., \& Hinings, C. (1993). Configurational Approaches to Organizational Analysis. Academy of Management Journal, 36(6), 1175-1195.

Miles, R. E., \& Snow, C. C. (1976). Organizations: New Concepts for New Forms. California Management Review, Spring, 62-73.

Miller, D. (1996). Configurations Re-visited. Strategic Management Journal, 17(7), 505-512.

Ministry of Trade and Industry. (1993). Ministry of Trade and Industry, National Industrial Strategy for Finland, Helsinki.

Mott, P. E. (1972). The Characteristics of Effective Organizations. New York: Harper \& Row.

Namiki, N. (1989). Miles and Snow's Typology of Strategy, Perceived Environmental Uncertainty, and Organizational Performance. Akron Business and Economic Review, 20(2), 72-88.

Narver, J., \& Slater, S. (1990, October). The Effect of a Market Orientation on Business Profitability. Journal of Marketing, 54, 20-35.

Nelson, R., \& Pack, H. (1996). The Asian Growth Miracle and Modem Growth Theory. The Economic Journal, 109(457), 416-436.

Numazaki, I. (1991). The Role of Personal Networks in The Making of Taiwan's Quanxiqiye. In Hamilton, G (Ed.), Business Networks and Economic Development in East and South East Asia. Centre for Asian Studies, University of Hong Kong

Nunnally, J. (1978). Psychometric Theory. New York: McGraw-Hill.

Oster, A. (1990). Modern Competitive Analysis. New York: Oxford University Press.

Owen, N. (1971). The Decline of Competition with Industrial Maturity: The Implications for Income Distribution in Hong Kong. Centre for Asian Studies, University of Hong Kong, Hong Kong.

Pack, H. (1993). Technology Gaps between Industrial and Developing Countries: Are There Dividends for Latecomers?. Proceedings of the World Bank Annual Conference on Development Economies 1992. Washington, DC: World Bank.

Pack, H., \& Page, J. (1994a). Endogenous Growth Theory: Intellectual Appeal and Empirical Shortcomings. The Journal of Economic Perspectives, 8(1), Winter, 55-72.

Pack, H., \& Page, J. (1994b). Accumulation Exports and Growth in the High Performing Asian Economies. Carnegie-Rochester Conference Series on Public Policy, 40, 199-236. 
Pelham, A. M., \& Wilson, D. T. (1996, December). A Longitudinal Study of the Impact of Market Structure, Firm Structure, Strategy and the Market Orientation Culture on Dimensions of Small-Firm Performance. Journal of the Academy of Marketing Science, 27-43.

Pitt, et. al. (1996). Market Orientation and Business Performance: Some European Evidence. International Marketing Review, 13(1), 5-18.

Porter, M. E. (1980). Competitive Strategy: Techniques for Analyzing Industries and Competitors. New York: Free Press.

Porter, M. E. (1985). Competitive Advantage. New York: Free Press.

Porter, M. E. (1990). The Competitive Advantage of Nations. London: Macmillan.

Redding, S. G. (1987, May,). The Study of Managerial Ideology Amongst Overseas Chinese Owner-Managers. Asia-Pacific Journal of Management, 167-177.

Redding, S. G. (1990). The Spirit of Chinese Capitalism. Berlin: de Gryter.

Redding, S. G. (1991). Weak Organizations and Strong Family Business Networks. In G. Hamilton (ed.), Business Networks and Economic Development in East and Southeast Asia (pp. 30-47). Hong Kong: Centre of Asian Studies, University of Hong Kong.

Redding, S. G. (1992). Capitalist Cooking Lessons. Asian Business, 28(11), 50-52.

Redding, S. G. (1995). Overseas Chinese Networks: Understanding the Enigma. Long Range Planning, 28(1), 61-69.

Redding, S. G., \& Pugh, D. S. (1986). The Formal and the Informal: Japanese and Chinese Organization Structures. The Enterprise and Management in East Asia (pp. 153-168). Hong Kong: Centre for Asian Studies, University of Hong Kong.

Reif, R., \& Sodini, S. (1997, Feburary). Hong Kong Industrialist, pp. 11-17.

Riedel, J. (1974). The Industrialization of Hong Kong. Tubingen J.C.B. Mohr (Paul Sieback).

Romer, P. (1993a). Idea Gaps and Object Gaps in Economic Development. Journal of Monetary Economies, 31, 543-573.

Romer, P. (1993b). Two Strategies for Economic Development: Using Ideas and Producing Ideas. Proceedings of the World Bank Annual Conference on Development Economics 1992, pp. 63-98. Washington, DC: World Bank.

Ruekert, R. (1992). Developing a Market Orientation: An Organizational Strategy Perspective. International Journal of Research in Marketing, 9(3), 225-245.

Ryan, E. (1961). The Value System of a Chinese Community in Java, PHD Dissertation. Harvard University.

Sabel, C. (1989). Flexible Specialization and the Re-emergence of Regional Economies. In P. Hirst \& J. Zeitlin (Eds.), Reversing Industrial Decline? Industrial Structural and Policy in Britain and Her Competitors. Oxford, Berg.

Seagrave, S. (1995). The Invisible Expire of The Overseas Chinese. London: Bantam.

Sit, et. al. (1979). Small Scale Industry in Laissez-Faire Economy: A Hong Kong Case Study. Centre of Asian Studies, University of Hong Kong.

Tan, J. J., \& Litschert, R. J. (1994). Environment-Strategy Relationship and Its Performance Implications: An Empirical Study of Chinese Electronics Industry. Strategic Management Journal, 15, 1-20.

Tang, H. (2012, July 19). Speech in the Federation of Hong Kong Industries Luncheon.

Taplin, \& Fagere. (1999). Managing Transitions: The Re-Organization of Two Clothing Manufacturing Firms in Hungary. Organization Studies, 20(5), 721-740.

The Federation of Hong Kong Industry. (2002). Hong Kong Industrialist.

Thurow, L. (1987). A Weakness in Process Technology Science. Cambridge Press.

Tong, C. K. (1991). Conceptual Authority, Differentiated Networks: The Social Organization of Chinese Firms in Singapore. In G. Hamilton (Ed.), Business Networks and Economic Development in East and South East Asia (pp. 176-200). Hong Kong Centre for Asian Studies, University of Hong Kong.

Trade Development Board. (1990). Export Manufacturing: Framework for Success. Wellington: New Zealand 
Trade Development Board.

Tu, I. C., (1991). Family Enterprises in Taiwan. In Hamilton, G (Ed.), Business Networks and Economic Development in East and South East Asia. Centre for Asian Studies, University of Hong Kong.

UNCTAD (United Nations Conference on Trade and Development). (1996). Exports, Capital Formation and growth. Trade and Development Report 1996, pp. 107-138. New York: United Nations.

Uzzi, B. (1997). Social Structure and Competition in Inter-Firm Networks: The Paradox of Embeddedness. Administrative Science Quarterly, 42, 35-67.

Venkatraman, N., \& Ramanujam, G. (1986). Measurement of Business Performance in Strategy Research: A Comparison of Approaches. Academy of Management Review, 11, 801-814.

Venkatraman. N. (1989). The Concept of Fit in Strategy Research: Toward Verbal and Statistical Correspondence. Academy of Management Review, 14(3), 423-444.

Wade, R. (1988). The Role of Government in Overcoming Market Failure: Taiwan, Republic of Korea and Japan. In Helen Hughes (Ed.), Achieving Industrialization in East Asia (pp. 129-63). Cambridge: Cambridge University Press.

Warr, P. G. (1994). Comparative and Competitive Advantage. Asia-Pacific Economic Literature, 8(2), 1-14.

Weber, M. (1951). The Religion of China: Confucianism and Taoism. The Free Press.

Weidenbaum, M. (1996). The Chinese Family Business Enterprise. California Management Review, 38(4), 141-156.

Weidenbaum, M., \& Hughes, S. (1996). The Bamboo Network: How Expatriate Chinese Entrepreneurs Are Creating A New Economic Superpower in Asia. New York: Free Press.

White, S. (2002). Rigor and Relevance in Asian Management: Where are We and Where can we go?. Asia Pacific Journal of Management, 19(2-3), 287-352.

Whitely, R. (1990). Eastern Asian Enterprise Structure and the Comparative Analysis of Forms of Business Organization. Organization Studies, 11(1), 47-74.

Whitley, R. (1991). The Social Construction of Business Systems in East Asia. Organization Studies, 12(1), 1-28.

Whitley, R. (1992). Business Systems in East Asia: Markets, Firms and Societies. London: Sage.

Wong, G. (1991). Business Groups in a Dynamic Environment: Interlocking Directorates in Hong Kong, 1976-1986. In Gary G. Hamilton (Ed.), Business Networks and Economic Development in East and Southeast Asia. Hong Kong: Centre of Asian Studies, University of Hong Kong.

Wong, P. B. (1996, October 4-6). Supply Infrastructure for Flexible Production: The Case of Hard Disk Drive Industry in Singapore. Paper Presented at the Conference on Economic Governance and Flexible Production in East Asia, Tsing Hua University, Taiwan.

Wong, S. L. (1985). The Chinese Family Firm: A Model. The British Journal of Sociology, 366(1), 58-72.

Wong, S. L. (1988). The Applicability of Asian Family Values to Other Sociocultural Settings. In P. Berger \& M. Hsino (Eds.), Search of an East Asian Development Model (pp. 134-155). New Transaction Books.

Wong, S. L. (1991). Chinese Entrepreneurs and Business Trust. In G. Hamilton (Ed.), Business Networks and Economic Development in East and South East Asia (pp. 13-29). Hong Kong Centre for Asian studies, University of Hong Kong.

Wong, S. L. (1995). Business Networks, Cultural Values and the State in Hong Kong and Singapore. In R. Brown (Ed.), Chinese Business Enterprise in Asia (pp. 136-153). London: Routledge.

World Bank. (1993). The East Asian Miracle: Economic Growth and Public Policy. Oxford University Press.

Yen, A., \& Ng. M. (1994). The Changing Role of the State in High-Tech Industrial Development: The Experience of Hong Kong. Environment and Planning C, Government and policy, 12, 449-472.

Young, A. (1992). A Tale of Two Cities: Factor Accumulation and Technological Change in Hong Kong and Singapore. National Bureau of Economic Research Macroeconomic Annual 1992. Cambridge, Mass: MIT Press.

Young, A. (1994a). Accumulation, Exports and Growth in the High Performing Asian Economies, a Comment. Carnegie-Rochester Conference Series on Public Policy, 40, 237-50. 
Young, A. (1994b). Lesson from the East Asian NICS: A Contrarian View. European Economic Review, 38, 964-73.

Youngson, R. (1982). Hong Kong Economic Growth and Policy. Hong Kong: Oxford University Press.

Yu, T. (1997). Entrepreneurship and Economic Development in Hong Kong. London: Routledge.

Yu, T. (1998). Adaptive Entrepreneurship and the Economic Development of Hong Kong. World Development, 26, 897-911.

Yu, T. (2001). Firms, Governments and Economic Change: An Entrepreneurial Perspective. Edward Elgar Publication.

Zahra, S., \& Covin, J. (1993). Business Strategy, Technology Policy and Firm Performance. Strategic Management Journal, 14, 451-478.

Zinn, et. al. (1996). Strategic Groups, Performance, and Strategic Response in the Nursing Home Country. Health Services Research, 29(2), 187-205.

\section{Copyrights}

Copyright for this article is retained by the author(s), with first publication rights granted to the journal.

This is an open-access article distributed under the terms and conditions of the Creative Commons Attribution license (http://creativecommons.org/licenses/by/4.0/). 